\title{
Lung Fluid Balance in Awake Newborn Lambs with Pulmonary Edema from Rapid Intravenous Infusion of Isotonic Saline
}

\author{
RICHARD D. BLAND AND MICHAEL A. BRESSACK \\ Cardiovascular Research Institute and Department of Pediatrics, University of California, San Francisco, California,
} USA

\begin{abstract}
Summary
To study pulmonary transvascular filtration of fluid and the normal adaptive response of newborn animals to excessive water in the lungs, we measured lung lymph flow, pulmonary vascular pressures, and the concentration of protein in lymph and plasma of nine unanesthetized 1- to 3-wk-old lambs, before, during, and after a rapid iv infusion of isotonic saline, $130-250 \mathrm{ml} / \mathrm{kg} \cdot \mathrm{hr}$ for 3-4 hr. During infusions, lung vascular pressures increased, the transvascular gradient of protein osmotic pressure decreased, and there was a 2- to 5-fold increase of lung lymph flow. When infusions stopped, lymph flow decreased, as the concentration of protein in plasma increased and pulmonary vascular pressures decreased to new steady-state levels. The concentration of protein in lymph did not change for several hours after the infusions. Body weight increased by $28 \%$ and extravascular lung water content was $19 \%$ above normal after saline; these changes were associated with mild tachypnea, hypercarbia, and hypoxemia. Sections of lung from these lambs had prominent cuffs of fluid surrounding large blood vessels.
\end{abstract}

\section{Speculation}

We attribute these findings to an efficient network of pulmonary lymphatic channels and a distensible pulmonary perivascular space, or watershed, that accommodates excess lung fluid postnatally until its subsequent drainage by the pulmonary lymphatics and microcirculation, without serious compromise of respiratory gas exchange. It is likely that these same mechanisms permit gradual removal of residual fetal lung liquid during postnatal pulmonary adaptation. Other developments that should hasten reabsorption of fluid from the lungs after birth are a reduction of pulmonary microvascular pressure, a high concentration of protein in the plasma, and expansion of the pulmonary microcirculation, providing greater surface area for absorption of protein-poor fetal lung liquid.

At birth, the lungs must accommodate a $40-50 \%$ increase in blood volume (28) and a large shift of residual liquid from potential air spaces into the interstitium, as pulmonary gas exchange begins. Few newborn infants fail or require assistance in meeting this challenge, a fact that speaks for an effective postnatal pulmonary plumbing system. Nevertheless, excessive intravascular infusions of fluid in the initial days of life may overload the circulation of some infants and cause pulmonary edema (7).

To examine the normal adaptive response of newborn animals to excessive fluid in the lung, we studied the movement of liquid and protein in the lungs of awake lambs during pulmonary edema induced by intravascular fluid overload. Staub (21) showed that steady-state pulmonary lymph flow and the concentration of protein in lymph reflect the net transvascular movement of water and protein in the lung, assuming that the concentration of protein in lymph approximates that in the pulmonary interstitium, as recent studies suggest it does $(15,27)$.

Erdmann et al. (8) showed that elevating pulmonary microvascular pressure in sheep increases filtration of fluid into the lungs, causing an increase in pulmonary lymph flow and a decrease in the concentration of protein in lymph. Bland et al. (3) found that lung lymph flow decreases as transvascular filtration of fluid diminishes.

We measured lung lymph flow and pulmonary vascular pressures of nine unanesthetized 1- to 3-wk-old lambs before, during, and after a rapid iv infusion of isotonic saline, $130-250 \mathrm{ml} / \mathrm{kg}$. $\mathrm{hr}$ for 3-4 hr. As pulmonary vascular pressures increased and protein osmotic pressures decreased during infusions, the flow of lymph from the lungs increased 2-to 5-fold, but extravascular lung water content was only $19 \%$ above normal, and there were small changes in the partial pressure of $\mathrm{O}_{2}$ and $\mathrm{CO}_{2}$ in arterial blood.

\section{MATERIALS AND METHODS}

\section{PREPARATION OF LAMBS FOR EXPERIMENTS}

Using methods previously described $(2,22)$, we surgically prepared nine newborn lambs to collect lung lymph and measure average pulmonary arterial ( $\overline{\mathrm{P}}$ pa), left atrial ( $\overline{\mathrm{P}}$ la $)$, and aortic blood pressures. The lambs (average birth weight $3.9 \mathrm{~kg}$., range $2.3-5.2$ $\mathrm{kg}$ ) had two thoracotomies, the first during the initial week of life, and the second 4-7 days later. They received anesthesia with halothane and nitrous oxide and were ventilated with a pistontype respirator (Model 607, Harvard Apparatus Co, Inc, Millis, MA) during surgery. Before and after surgery, and between experiments, the lambs remained with their ewes for feeding and warmth.

In the first operation, we placed polyvinyl catheters in the thoracic aorta, both atria, and the pulmonary artery. After the lambs recovered, a second thoracotomy was done to obtain pulmonary lymph. In lambs, about two-thirds of the lung lymph flows into the thoracic duct by way of the caudal mediastinal lymph node $(12,26)$, which is a long, narrow structure located in the posterior mediastinum on the right side of the chest. We resected systemic contributions to that lymph node and inserted a heparin-coated (TDMAC processing, Polyscience Inc, Warrington, PA) polyvinyl catheter (Tygon Tubing, Akron, $\mathrm{OH}$ ), internal diameter $0.38 \mathrm{~mm}$, into the efferent duct of that node for collection of nearly pure pulmonary lymph. Previous studies on adult sheep showed that this fluid is not contaminated by lymph of systemic origin (22). We tunneled the catheter beneath the pleura, brought it through the chest wall, sutured it to the skin, and protected it with a canvas pouch. In addition, we placed a polyvinyl catheter in the pleural space for postoperative drainage of pleural fluid and air. The lambs had at least 2 days to recover, and experiments did 
not begin until the pleural cavity was free of fluid and the lymph contained no visible blood and flowed at a steady rate.

\section{DESCRIPTION OF EXPERIMENTS}

The average weight of the lambs at the time of the experiments was $5.5 \mathrm{~kg}$ (range, $4.1-7.1 \mathrm{~kg}$ ), their average age was 13 days (range, 7-24 days). During experiments, the lambs were erect without restraints in a cardboard box. We measured $\overline{\mathrm{P}} \mathrm{pa}, \overline{\mathrm{P}} \mathrm{la}$, and phasic aortic blood pressure continuously with calibrated pressure transducers (Statham P23 Dc, Statham Instruments, Inc, Oxnard, CA) and a four-channel amplifier-recorder (Grass model 7B polygraph, 7DAE amplifiers, and 7PIB preamplifiers, Grass Instrument Co, Quincy, MA). Zero-reference level for all pressure measurements was a line drawn at the time of surgery on the lamb's skin at the level of the left atrium.

We measured lymph flow to the nearest $0.01 \mathrm{ml}$ at $30-\mathrm{min}$ intervals for at least $2 \mathrm{hr}$ during a steady-state baseline period, 3$4 \mathrm{hr}$ during rapid infusion of isotonic saline $(154 \mathrm{mEq} / \mathrm{liter})$ at a constant rate (average rate $182 \mathrm{ml} / \mathrm{kg} \cdot \mathrm{hr}$, range, $130-250 \mathrm{ml} / \mathrm{kg}$. $\mathrm{hr}$ ), into the right atrium, and for $2-3 \mathrm{hr}$ after stopping the infusion. We collected samples of lymph and blood in heparinized test tubes every $30 \mathrm{~min}$, with blood specimens taken at the midpoint of each lymph collection period.

During baseline, infusion, and postinfusion periods, we measured heart rate, respiratory frequency, and rectal temperature, and obtained samples of arterial blood at frequent intervals for measurement of packed cell volume (hematocrit), $\mathrm{pH}$, and blood gas tensions. At the end of each phase of the experiments, the lambs were weighed to the nearest $0.05 \mathrm{~kg}$.

\section{POSTMORTEM STUDIES}

At the conclusion of experiments on each animal, we injected pentobarbital sodium, $20 \mathrm{mg} / \mathrm{kg}$, into the right atrium, placed the lamb supine, ventilated the lungs with air via the respirator, and rapidly split the sternum to excise the lungs. We clamped the hili of both lungs at end-inspiration, an airway pressure of $25 \mathrm{~cm} \mathrm{H}_{2} \mathrm{O}$, with the heart still beating, and removed the lungs for measurement of extravascular water and dry lung tissue weight. This was done with five lambs immediately after a $3-\mathrm{hr}$ infusion of saline, on a day subsequent to the aforementioned three-part experiments in which lymph was collected. We compared the results to measurements of extravascular lung water content previously done with normal control lambs (2).

From the five lambs killed immediately after an infusion of saline, we removed and quickly froze the inflated lungs in liquid nitrogen, prepared a piece of one lung for microscopy by the method of Storey and Staub (24), and examined frozen sections for histologic evidence of pulmonary edema.

\section{ANALYTIC METHODS}

We centrifuged samples of lymph and blood and measured the concentration of protein in the supernates by the Biuret method (10) and albumin by the Bromcresol green method (17). Arterial blood gas tensions were measured on a blood gas analyzer (AcidBase Analyzer PHM 71, Radiometer Co, Copenhagen, Denmark), with calibration at $40^{\circ} \mathrm{C}$, the normal body temperature of lambs.

We calculated the weight of extravascular lung water per gram of dry lung tissue, exclusive of blood, for all lambs by a modification $(6,8)$ of the method described by Pearce et al. (16). We expressed pulmonary lymph flow and protein flow (lymph flow $\times$ lymph protein concentration) relative to the weight of dry, bloodless lung tissue. In addition, protein flow was expressed in relation to the concentration of protein in the plasma of each animal.

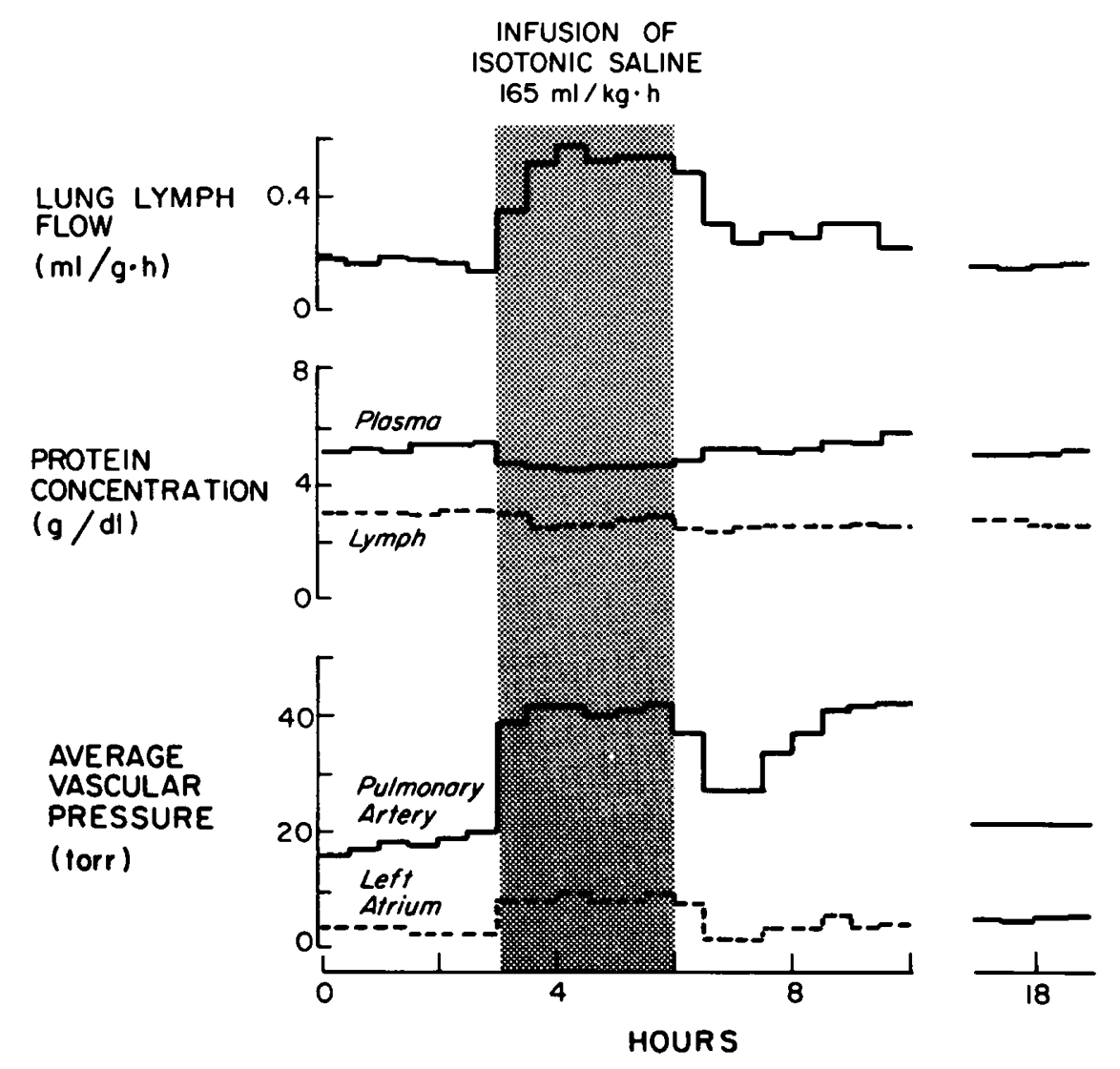

Fig. 1. Lymph flow/g of dry lung tissue, concentrations of protein in lymph and plasma, and average vascular pressures in one lamb before, during, and after a rapid, constant intravascular infusion of isotonic saline at a rate of $165 \mathrm{ml} / \mathrm{kg}$ body weight per hour for $3.5 \mathrm{hr}$. For comparison, measurements obtained 17-19 hr after the experiment began are included. 


\section{STATISTICS}

We compared average steady-state measurements made in three two-hour periods, before, during, and after infusion of saline. We used paired $t$ tests (19), corrected for multiple testing (25), and accepted $P<0.05$ as indicative of significant differences. Measurements of postmortem lung water content after saline infusions and those made under baseline conditions were compared by an unpaired $t$ test. All summary results in both the text and the tables are expressed as the mean \pm 1 SEM.

\section{RESULTS}

Figure 1 illustrates the results of a typical experiment in which we infused isotonic saline intravascularly at a rate of $165 \mathrm{ml} / \mathrm{kg}$. hr for $3.5 \mathrm{hr}$. After a 2-hr steady-state baseline period, we began the infusion of saline. In response to the increase of pulmonary vascular pressures and the reduced concentration of protein in plasma, lymph flow tripled and the concentration of protein in lymph decreased. After reaching a new steady-state, the infusion was stopped, and vascular pressures diminished, plasma protein concentration increased, and lymph flow decreased to a new plateau. It is notable that the concentration of protein in lymph remained low for several hours, despite the increase of plasma protein concentration and the reduced intravascular pressures. Several hours later, vascular pressures and protein concentrations had returned to preinfusion levels.

In nine such experiments, body weight increased by an average of $29 \%$ during the infusion of saline, heart rate increased from 189 \pm 7 to $235 \pm 9$ beats/min, and then decreased to $208 \pm 10$ beats/ min during the postinfusion period. The pattern was similar for arterial blood pressure $(89 \pm 3 / 52 \pm 1$ to $110 \pm 3 / 53 \pm 5$ to 100 $\pm 2 / 56 \pm 4$ torr) and respiratory frequency ( $54 \pm 6$ to $71 \pm 5$ to $64 \pm 8$ breaths/min). Except for diastolic blood pressure, all of these differences were significant.

Table 1 is a summary of the results pertaining to the movement of lung water and protein for these nine experiments. $\overline{\text { Ppa and }} \overline{\mathrm{P}}$ la increased during fluid overload, and then decreased, remaining significantly above baseline pressures for $3 \mathrm{hr}$ after the infusions. The concentration of protein in both lymph and plasma decreased during infusions, with a significant change in the lymph:plasma

Table 1. Vascular pressures, protein concentrations, and lung lymph flow of nine lambs in 2-hr "steady state" periods before, during, and after rapid, constant intravascular infusions of isotonic saline

\begin{tabular}{|c|c|c|c|c|c|c|c|c|c|c|}
\hline \multirow[b]{3}{*}{ Lamb } & \multirow{3}{*}{$\begin{array}{l}\text { Rate of in- } \\
\text { fusion of } \\
\text { isotonic sa- } \\
\text { line (ml/kg. } \\
\text { hr) }\end{array}$} & \multirow{3}{*}{$\begin{array}{c}\text { Time relative } \\
\text { to the infu- } \\
\text { sion }\end{array}$} & & & \multicolumn{4}{|c|}{ Protein concentrations } & \multirow[b]{3}{*}{$\begin{array}{l}\text { Lymph flow } \\
\left(\mathrm{ml} / \mathrm{hr} \cdot \mathrm{g}^{2}\right)\end{array}$} & \multirow{3}{*}{$\begin{array}{c}\text { Protein flow } \\
(\mathrm{mg} / \mathrm{hr} \cdot \mathrm{g} \cdot \\
\left.\mathrm{gp}_{\mathrm{p}}{ }^{3}\right)\end{array}$} \\
\hline & & & \multicolumn{2}{|c|}{ Vascular pressures } & \multicolumn{2}{|c|}{ Lymph } & \multicolumn{2}{|c|}{ Plasma } & & \\
\hline & & & $\begin{array}{c}\overline{\mathbf{P}}_{\text {pa }} \\
\text { (torr) }\end{array}$ & $\begin{array}{c}\text { Pिla } \\
\text { (torr) }\end{array}$ & $\begin{array}{l}\text { Total } \\
(\mathrm{g} / \mathrm{dl})\end{array}$ & $\%$ Alb $^{\prime}$ & $\begin{array}{l}\text { Total } \\
(\mathrm{g} / \mathrm{dl}) \\
\end{array}$ & $\% A^{\prime} b^{1}$ & & \\
\hline \multirow[t]{3}{*}{1} & 250 & Before & 15 & 3 & 3.13 & 48 & 4.82 & 36 & 0.08 & 0.52 \\
\hline & & During & 33 & 13 & 1.59 & 48 & 3.78 & 34 & 0.16 & 0.67 \\
\hline & & After & 21 & 5 & 1.93 & 49 & 4.25 & 34 & 0.11 & 0.50 \\
\hline \multirow[t]{3}{*}{2} & 130 & Before & 18 & 6 & 3.19 & 49 & 5.00 & 42 & 0.07 & 0.45 \\
\hline & & During & 30 & 16 & 1.79 & 55 & 3.63 & 43 & 0.16 & 0.79 \\
\hline & & After & 22 & 10 & 1.73 & 53 & 4.47 & 41 & 0.10 & 0.39 \\
\hline \multirow[t]{3}{*}{3} & 200 & Before & 21 & 2 & 3.79 & 40 & 5.45 & 37 & 0.11 & 0.76 \\
\hline & & During & 33 & 18 & 2.41 & 43 & 3.58 & 37 & 0.35 & 2.36 \\
\hline & & After & 31 & 10 & 1.20 & 44 & 4.56 & 38 & 0.31 & 0.82 \\
\hline \multirow[t]{3}{*}{4} & 165 & Before & 18 & 5 & 3.24 & 43 & 5.45 & 36 & 0.16 & 0.95 \\
\hline & & During & 35 & 14 & 2.39 & 44 & 4.05 & 38 & 0.50 & 2.95 \\
\hline & & After & 33 & 9 & 1.46 & 45 & 4.93 & 38 & 0.34 & 1.01 \\
\hline \multirow[t]{3}{*}{5} & 195 & Before & 19 & 4 & 3.31 & 42 & 6.35 & 40 & 0.15 & 0.78 \\
\hline & & During & 31 & 10 & 1.99 & 50 & 4.60 & 39 & 0.51 & 2.20 \\
\hline & & After & 23 & 6 & 1.74 & 45 & 4.93 & 43 & 0.40 & 1.41 \\
\hline \multirow[t]{3}{*}{6} & 165 & Before & 18 & 3 & 2.89 & 47 & 4.98 & 41 & 0.18 & 1.02 \\
\hline & & During & 41 & 9 & 2.71 & 43 & 4.35 & 41 & 0.55 & 3.45 \\
\hline & & After & 39 & 5 & 2.52 & 44 & 5.22 & 42 & 0.29 & 1.39 \\
\hline \multirow[t]{3}{*}{7} & 150 & Before & 22 & 1 & 2.89 & 40 & 4.73 & 34 & 0.17 & 1.01 \\
\hline & & During & 43 & 11 & 1.90 & 44 & 3.51 & 36 & 0.28 & 1.50 \\
\hline & & After & 38 & 9 & 1.86 & 44 & 3.70 & 44 & 0.23 & 1.14 \\
\hline \multirow[t]{3}{*}{8} & 195 & Before & 18 & 2 & 3.83 & 49 & 5.59 & 39 & 0.13 & 0.88 \\
\hline & & During & 35 & 12 & 1.58 & 42 & 3.71 & 44 & 0.66 & 2.81 \\
\hline & & After & 32 & 8 & 0.99 & 41 & 4.66 & 41 & 0.31 & 0.98 \\
\hline \multirow[t]{3}{*}{9} & 190 & Before & 16 & 3 & 2.60 & 40 & 5.00 & 33 & 0.14 & 0.73 \\
\hline & & During & 30 & 10 & 1.30 & 40 & 3.61 & 22 & 0.51 & 1.85 \\
\hline & & After & 16 & 3 & 1.41 & 47 & 4.40 & 30 & 0.31 & 0.98 \\
\hline$\overline{\mathbf{X}}$ & 178 & Before & 18 & 3 & 3.21 & 44 & 5.26 & 37 & 0.13 & 0.79 \\
\hline \multirow{5}{*}{$\begin{array}{l}\mathbf{A} \\
\pm S_{\bar{x}}\end{array}$} & \pm 11 & & \pm 1 & \pm 1 & \pm 0.14 & \pm 1 & 0.17 & \pm 1 & \pm 0.01 & \pm 0.07 \\
\hline & & During & $35^{4}$ & $13^{4}$ & $1.96^{4}$ & 46 & $3.87^{4}$ & 37 & $0.41^{4}$ & $2.06^{4}$ \\
\hline & & & \pm 2 & \pm 1 & \pm 0.15 & \pm 2 & \pm 0.13 & \pm 2 & \pm 0.06 & \pm 0.32 \\
\hline & & After & $28^{5,6}$ & $7^{5,6}$ & $1.65^{5}$ & 46 & $4.57^{5,6}$ & 38 & $0.28^{5,6}$ & $0.96^{6}$ \\
\hline & & & \pm 3 & \pm 1 & \pm 0.15 & \pm 1 & \pm 0.15 & \pm 1 & \pm 0.04 & \pm 0.12 \\
\hline
\end{tabular}

${ }^{1}$ Percent of concentration of total protein that is albumin.

${ }^{2}$ Lymph flow relative to dry lung tissue, exclusive of blood.

${ }^{3}$ Protein flow (lymph flow $X$ protein concentration in lymph) relative to dry lung tissue, exclusive of blood, and plasma protein concentration.

${ }^{4}$ Average measurement during infusion significantly different from average measurement before infusion, $P<0.05$.

${ }^{5}$ Average measurement after infusion significantly different from average measurement before infusion, $P<0.05$.

${ }^{6}$ Average measurement after infusion significantly different from average measurement during infusion, $P<0.05$. 
protein ratio from $0.61 \pm 0.02$ to $0.50 \pm 0.04$. After the infusions, the concentration of protein in plasma increased, but remained less than the baseline concentration; the concentration of protein in lymph did not increase after saline, causing a further decline in the ratio of lymph protein to plasma protein concentration (from $0.50 \pm 0.04$ to $0.36 \pm 0.03$ ). The albumin fraction of the total protein concentration in lymph and plasma did not change significantly during the course of the experiments.

On average, lymph flow more than tripled during the infusions, and then decreased to just over twice the baseline flow rate in the succeeding $3 \mathrm{hr}$. Changes in protein flow reflected changes in lymph flow, but were of smaller magnitude.

During the three phases of the experiments, arterial oxygen tension decreased progressively from $78 \pm 3$ to $68 \pm 6$ to $58 \pm 4$ torr, average carbon dioxide tension increased from $38 \pm 1$ to 47 \pm 3 to $49 \pm 4$ torr, and $\mathrm{pH}$ decreased from $7.47 \pm 0.01$ to $7.23 \pm$ 0.02 to $7.19 \pm 0.03$. Hematocrit decreased during the infusions from $25 \pm 2$ to $21 \pm 1$, and then increased to $23 \pm 2$ during the postinfusion phase.

\section{POSTMORTEM FINDINGS}

Extravascular lung water per gram of dry lung tissue, exclusive of blood, averaged $5.72 \pm 0.35 \mathrm{~g}, 19 \%$ greater than the water content of lungs from normal control lambs $(4.82 \pm 0.11 \mathrm{~g})$ (2). In sections of lung taken from four of five lambs after infusion of saline, there were substantial cuffs of fluid surrounding pulmonary blood vessels, indicative of moderately severe interstitial pulmonary edema. Figure 2 shows photomicrographs of sections of lung from a normal 2-wk-old lamb and one killed after a 3-hr iv infusion of saline, demonstrating an obvious difference in the amount and distribution of water in the lungs.

\section{DERIVED DATA}

We estimated the transvascular gradient for hydraulic pressure in the lung by the formula of Gaar et al. $(\mathrm{P}=\mathrm{Pla}+0.4[\overline{\mathrm{P}} \mathrm{pa}-$ Pla]) (9), assuming that this relationship is applicable to the pulmonary circulation of newborn lambs and that tissue pressure equals alveolar pressure (21). We derived protein osmotic pressures from the data of Landis and Pappenheimer (13), using our measurements of protein concentration in plasma and lymph to calculate intra- and extravascular protein osmotic pressures. Table 2 is a summary of this data, indicating that infusions of saline substantially increased pulmonary microvascular pressure and reduced the transvascular gradient of protein osmotic pressure. Stopping the infusions led to a considerable increase in the protein gradient and a simultaneous decrease in the gradient of hydraulic pressure.

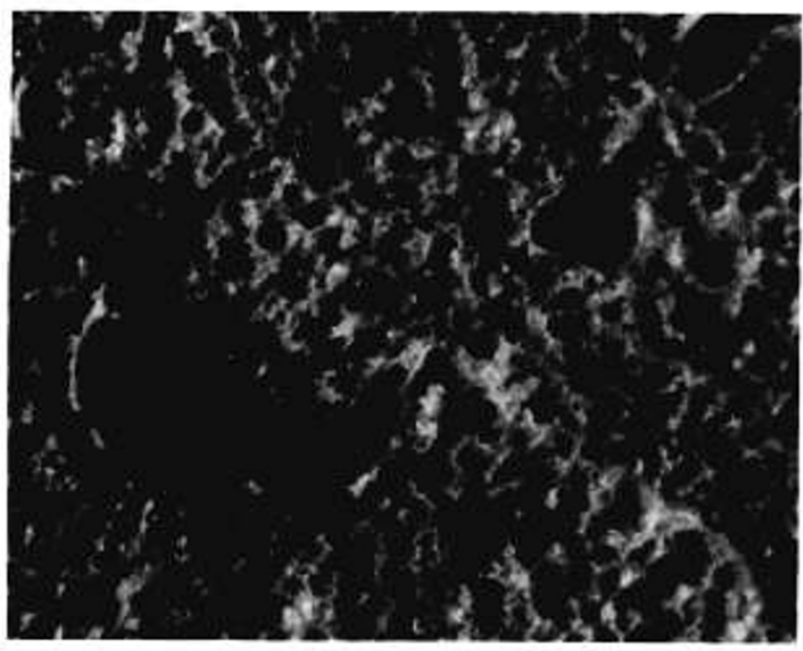

\section{DISCUSSION}

Filtration of fluid in the pulmonary microcirculation depends on differences between intravascular and extravascular hydraulic and protein osmotic pressures in the lung, permeability characteristics of the pulmonary microvascular membrane, and the amount of vascular surface area for exchange of water and solute in the lungs (20). In our experiments, rapid and sustained intravascular infusions of saline into lambs caused pulmonary microvascular pressure to increase, with an associated decrease in the transvascular gradient of protein osmotic pressure. The result was a substantial increase in transvascular filtration of fluid, demonstrated by a 2 - to 5 -fold increase in lung lymph flow.

In all lambs, when infusions of saline stopped, pulmonary microvascular pressure decreased, and the concentration of protein in plasma increased, but there was no significant change in the concentration of protein in lymph. These developments inhibited transvascular movement of fluid into the lung, causing lymph flow to decrease. There was a consistent and direct relationship between pulmonary lymph flow and the sum of forces governing filtration of fluid in the lung, as Table 2 shows. This observation was similar to that of Bowers et al. (5), who studied the response of adult sheep to smaller intravascular infusions of saline.

Changes in the transvascular flow of protein reflected changes in lymph flow, but were of smaller magnitude, as would be expected with a pressure-induced change in transvascular filtration of fluid (8), associated with microvascular sieving of protein. In these studies, nothing was done to influence the permeability to protein of the pulmonary microvascular membrane. It is not surprising, therefore, that [albumin]:[globulin] in lymph did not change significantly during or after infusions of saline, suggesting that there was no appreciable alteration in the capacity of the microvascular membrane to sieve proteins of large molecular weight. From our results, it cannot be determined if infusions of saline increased the pulmonary microvascular surface area for exchange of fluid, but it is reasonable to infer that substantial increases in vascular pressures from excessive intravascular fluid would cause recruitment of blood vessels through which there is intermittent or no blood flow under baseline conditions.

Guyton and Lindsay (11) discovered that by halving the intravascular protein osmotic pressure of dogs they could produce pulmonary edema at left atrial pressures less than half that required to cause pulmonary edema in the presence of normal concentrations of protein in plasma. Therefore, it was surprising to find that these lambs tolerated such large, sustained intravascular infusions of fluid with so little distress and so little deterioration in the pressures of gas in arterial blood.

Did the response in lymph flow prevent significant pulmonary

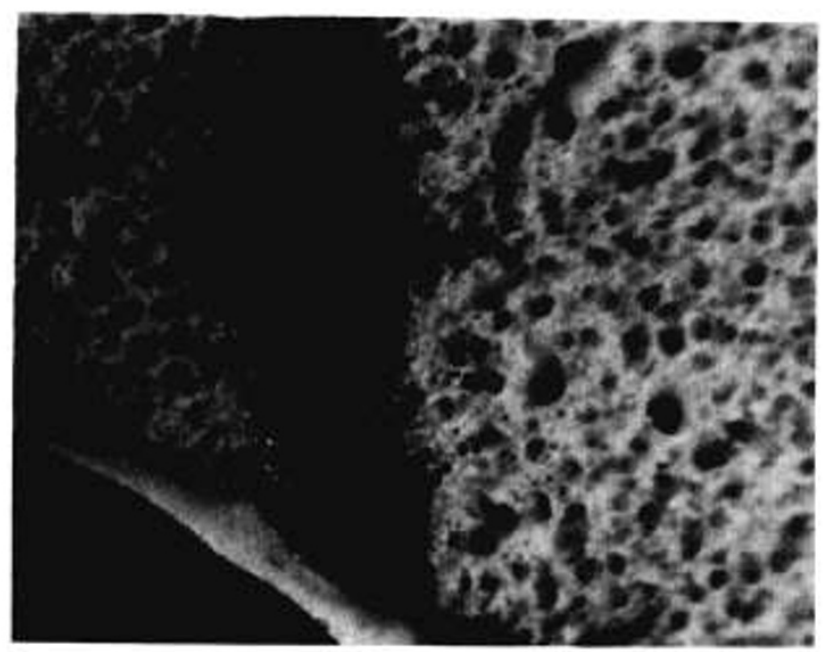

Fig. 2. Sections of lung, frozen in liquid nitrogen at an inflation pressure of $25 \mathrm{~cm} \mathrm{H}_{2} \mathrm{O}$. The one on the left is from a normal 2-wk-old lamb; the one on the right is from a lamb killed immediately after a 3-hr infusion of saline. Note the prominent cuffs of fluid surrounding pulmonary vessels near a bronchus in the lung removed after the infusion of saline. Magnification $8.5 X$. 
Table 2. Derived data for pulmonary microvascular pressure and protein osmotic pressure of lymph and plasma related to lymph flow in lambs with saline-induced pulmonary edema

\begin{tabular}{|c|c|c|c|c|c|c|c|}
\hline \multirow[b]{2}{*}{ Lamb } & \multirow[b]{2}{*}{$\begin{array}{l}\text { Time relative to } \\
\text { the infusion of sa- } \\
\text { line }\end{array}$} & \multirow[b]{2}{*}{$\begin{array}{l}\text { Pulmonary microvas- } \\
\text { cular pressure }(\overline{\mathrm{P}} \mathrm{mv}) \\
\overline{\mathrm{P}} \text { la }+0.4(\overline{\mathrm{P}} \text { pa- } \overline{\mathrm{P}} \mathrm{la})(9) \\
\text { (torr) }\end{array}$} & \multicolumn{3}{|c|}{ Protein osmotic pressures $(\pi)^{1}$} & \multirow[b]{2}{*}{$\begin{array}{c}\text { Sum of pressures } \\
\text { (torr) }\end{array}$} & \multirow[b]{2}{*}{$\begin{array}{l}\text { Lymph flow } \\
(\mathrm{ml} / \mathrm{hr} \cdot \mathrm{g})^{3}\end{array}$} \\
\hline & & & $\begin{array}{l}\text { Lymph } \\
\text { (torr) }\end{array}$ & $\begin{array}{c}\text { Plasma } \\
\text { (torr) }\end{array}$ & $\begin{array}{c}\text { Transvascular } \\
\text { gradient } \\
\text { (torr) }\end{array}$ & & \\
\hline \multirow[t]{3}{*}{1} & Before & 7.8 & 7.9 & 12.3 & 4.4 & 3.4 & 0.08 \\
\hline & During & 21.0 & 3.8 & 9.2 & 5.4 & 15.6 & 0.16 \\
\hline & After & 11.4 & 4.7 & 10.6 & 5.9 & 5.5 & 0.11 \\
\hline \multirow[t]{3}{*}{2} & Before & 10.8 & 8.1 & 13.1 & 5.0 & 5.8 & 0.07 \\
\hline & During & 21.6 & 4.5 & 9.1 & 4.6 & 17.0 & 0.16 \\
\hline & After & 14.8 & 4.3 & 11.5 & 7.2 & 7.6 & 0.10 \\
\hline \multirow[t]{3}{*}{3} & Before & 9.6 & 9.5 & 14.4 & 4.9 & 4.7 & 0.11 \\
\hline & During & 24.0 & 5.8 & 8.8 & 3.0 & 21.0 & 0.35 \\
\hline & After & 18.4 & 2.8 & 11.6 & 8.8 & 9.6 & 0.31 \\
\hline \multirow[t]{3}{*}{4} & Before & 10.2 & 8.0 & 14.3 & 6.3 & 3.9 & 0.16 \\
\hline & During & 22.8 & 5.8 & 10.2 & 4.4 & 18.4 & 0.50 \\
\hline & After & 17.8 & 3.4 & 12.7 & 9.3 & 8.5 & 0.34 \\
\hline \multirow[t]{3}{*}{5} & Before & 10.0 & 8.2 & 17.6 & 9.4 & 0.6 & 0.15 \\
\hline & During & 18.4 & 4.9 & 11.8 & 6.9 & 11.5 & 0.51 \\
\hline & After & 12.8 & 4.2 & 13.0 & 8.8 & 4.0 & 0.40 \\
\hline \multirow[t]{3}{*}{6} & Before & 9.0 & 7.2 & 13.0 & 5.8 & 3.2 & 0.18 \\
\hline & During & 21.8 & 6.6 & 11.1 & 4.5 & 17.3 & 0.55 \\
\hline & After & 18.6 & 6.1 & 13.8 & 7.7 & 10.9 & 0.29 \\
\hline \multirow[t]{3}{*}{7} & Before & 9.4 & 6.9 & 12.0 & 5.1 & 4.3 & 0.17 \\
\hline & During & 23.8 & 4.5 & 8.5 & 4.0 & 19.8 & 0.28 \\
\hline & After & 20.6 & 4.4 & 9.0 & 4.6 & 16.0 & 0.23 \\
\hline \multirow[t]{3}{*}{8} & Before & 8.4 & 9.9 & 14.9 & 5.0 & 3.4 & 0.13 \\
\hline & During & 21.2 & 3.7 & 9.4 & 5.7 & 15.5 & 0.66 \\
\hline & After & 17.6 & 2.3 & 12.0 & 9.7 & 7.9 & 0.31 \\
\hline \multirow[t]{3}{*}{9} & Before & 8.2 & 6.2 & 12.8 & 6.6 & 1.6 & 0.14 \\
\hline & During & 18.0 & 3.0 & 8.4 & 5.4 & 12.6 & 0.51 \\
\hline & After & 8.2 & 3.4 & 10.9 & 7.5 & 0.7 & 0.31 \\
\hline$\overline{\mathbf{X}}$ & Before & 9.3 & 8.0 & 13.8 & 5.8 & 3.4 & 0.13 \\
\hline \multirow[t]{5}{*}{ $\pm S_{\bar{x}}$} & & \pm 0.3 & \pm 0.4 & \pm 0.6 & \pm 0.5 & \pm 0.5 & \pm 0.01 \\
\hline & During & $21.4^{4}$ & $4.7^{4}$ & $9.6^{4}$ & $4.9^{4}$ & $16.5^{4}$ & $0.41^{4}$ \\
\hline & & \pm 0.7 & \pm 0.4 & \pm 0.4 & \pm 0.4 & \pm 1.0 & \pm 0.06 \\
\hline & After & $15.6^{5,6}$ & $4.0^{5}$ & $11.7^{5,6}$ & $7.7^{5,6}$ & $7.9^{5,6}$ & $0.28^{5,6}$ \\
\hline & & \pm 1.4 & \pm 0.4 & \pm 0.5 & \pm 0.6 & \pm 1.4 & \pm 0.4 \\
\hline
\end{tabular}

' Derived from the curves of Landis and Pappenheimer (13), based on actual measurements of fractional protein concentrations.

${ }^{2}$ Calculated as estimated pulmonary microvascular pressure minus the difference between protein osmotic pressures in plasma and lymph.

${ }^{3}$ Lymph flow relative to dry lung tissue, exclusive of blood.

${ }^{4}$ Derived data during infusion significantly different than before infusion, $P<0.05$.

${ }^{5}$ Derived data after infusion significantly different than before infusion, $P<0.05$.

${ }^{6}$ Derived data after infusion significantly different than during infusion, $P<0.05$.

edema? How much fluid stayed in the lungs and where in the parenchyma did it go? To answer these questions, we did postmortem studies of lambs killed immediately after a 3-hr infusion of saline (total volume of infusion averaged 55\% of body weight). Body weight increased by $29 \%$, extravascular lung water content was $19 \%$ greater than that of normal control lambs of a comparable age (2), and there were prominent cuffs of fluid in the tissue space surrounding large blood vessels after infusions of saline. These cuffs were similar to those observed by Snashall et al. (18) after they infused crystalloid solution iv into anesthetized dogs with ligated renal pedicles.

This distensible perivascular space, referred to as a "pulmonary sump" by Macklin (14), contains lymphatic channels and a loose meshwork of connective tissue into which fluid flows in the early stage of pulmonary edema (23). It is this space that accommodates residual fetal lung liquid soon after birth, allowing gradual reabsorption of water during postnatal pulmonary adaptation $(1,4)$. The presence of these reservoirs in the pulmonary interstitium after infusions of saline may explain why the concentration of protein in lymph remained low for several hours, despite reduced intravascular pressure and increased concentrations of protein in plasma. Whereas most of the lambs recovered without treatment, those with the most severe and sustained pulmonary edema benefited from rapid iv infusion of furosemide (4).

Our measurements of lymph flow and extravascular lung water suggest that the net amount of excess fluid filtered into the lungs during a 3-hr infusion of saline was approximately $50 \%$ of the normal extravascular lung water content. Of this amount, almost two-thirds drained from the lung by way of the lymphatic system, whereas the remainder stayed in the lung, mostly in its loose perivascular tissue space, where it had only a modest effect on respiratory gas exchange.

\section{REFERENCES AND NOTES}

1. Aherne, W., and Dawkins, M. J. R.: The removal of fluid from the pulmonary airways after birth in the rabbit, and the effect on this of prematurity and prenatal hypoxia. Biol. Neonat., 7: 214 (1964).

2. Bland, R. D., and McMillan, D. D.: Lung fluid dynamics in awake newborn lambs. J. Clin. Invest., 60: 1107 (1977).

3. Bland, R. D., McMillan, D. D., and Bressack, M. A.: Decreased pulmonary transvascular fluid filtration in awake newborn lambs after intravenous furosemide. J. Clin. Invest., 62: 601 (1978).

4. Bland, R. D., McMillan, D. D., and Bressack. M. A.: Movement of water and protein in the fetal and newborn lung. Ann. Rech. Vet., 8: 418 (1977). 
5. Bowers, R. E., Brigham, K. L., and Harris, T. R.: Effects of rapid saline infusion on lung fluid balance in awake sheep. Clin. Res., 25: 36A (1977).

6. Brigham, K. L., Woolverton, W. C., Blake, L. H., and Staub, N. C.: Increased sheep lung vascular permeability caused by Pseudomonas bacteremia. J. Clin. Invest., 54: 792 (1974).

7. Cole, V. A., Normand, I. C. S., Reynolds, E. O. R., and Rivers, R. P. A.: Pathogenesis of hemorrhagic pulmonary edema and massive pulmonary hemorrhage in the newborn. Pediatrics, 51: 175 (1973).

8. Erdmann, A. J., IlI, Vaughan, T. R., Jr., Brigham, K. L., Woolverton, W. C., and Staub, N. C.: Effect of increased vascular pressure on lung fluid balance in unanesthetized sheep. Circ. Res., 37: 271 (1975).

9. Gaar, K. A., Taylor, A. E., Owens, L. J., and Guyton, A. C.: Pulmonary capillary pressure and filtration coefficient in the isolated perfused lung. Am. J. Physiol., 213: 910 (1967).

10. Gornall, A. G., Bardawill. C. J., and David, M. M.: Determination of serum proteins by means of the Biuret reaction. J. Biol. Chem., 177: 751 (1949).

11. Guyton, A. C., and Lindsay, A. W.: Effect of elevated left atrial pressure and decreased plasma protein concentration on the development of pulmonary edema. Circ. Res., 7: 649 (1959).

12. Humphreys, P. W. Normand, 1. C. S., Reynolds, E. O. R., and Strang, L. B.: Pulmonary lymph flow and the uptake of liquid from the lungs of the lamb at the start of breathing. J. Physiol. (London), 193: 1 (1967).

13. Landis, E. M., and Pappenheimer, J. R.: Exchange of substances through the capillary walls. In: W. Hamilton: Handbook of Physiology 2. Sect. 2, Circulation p. 961 (Washington, D. C., American Physiological Society, 1963).

14. Macklin, C. C.: Pulmonary sumps, dust accumulations, alveolar fluid and lymph vessels. Acta Anatomica, 23: 1 (1954)

15. Nicolaysen, G. A., Nicolaysen, A., and Staub, N. C.: A quantitative radioautographic comparison of albumin concentration in different sized lymph vessels in normal mouse lungs. Microvasc. Res., 10: 138 (1975).

16. Pearce, M. L., Yamashita, J., and Beazell, J.: Measurement of pulmonary edema. Circ. Res., 16: 482 (1965).

17. Rodkey, F. L.: Direct spectrophotometric determination of albumin in human serum. Clin. Chem., $11: 478$ (1965).

18. Snashall, P. D., Weidner, W. J., and Staub, N. C.: Extravascular lung water after extracellular fluid volume expansion in dogs. J. Appl. Physiol., 42: 624 (1977).

Copyright $(C) 1979$ International Pediatric Research Foundation, Inc. $0031-3998 / 79 / 1309-1037 \$ 02.00 / 0$
19. Snedecor, G., and Cochran, W.: Statistical Methods, p. 91 (lowa State University Press, Ames, Iowa, 1972).

20. Starling, E.: On the absorption of fluids from the connective tissue spaces. J. Physiol. (London), 19: 312 (1895-6).

21. Staub, N. C.: Pulmonary edema. Physiol. Rev., $54: 687$ (1974).

22. Staub, N. C., Bland, R. D., Brigham, K. L., Demling, R. H., Erdmann, A. J., III, and Woolverton, W. C.: Preparation of chronic lung lymph fistulas in sheep. J. Surg. Res., 19: 315 (1975).

23. Staub, N. C., Nagano, H., and Pearce, M. L.: Pulmonary edema in dogs, especially the sequence of fluid accumulation in lungs. J. Appl. Physiol., 22: 227 (1967).

24. Storey, W. F., and Staub, N. C.: Ventilation of terminal air units. J. Appl. Physiol., 17: 179 (1962).

25. Tukey, J. W.: Some thoughts on clinical trials, especially problems of multiplicity. Science, 198: 679 (1977).

26. Vaughan, T. R., Jr., Erdmann, A. J., III, Brigham, K. L., Woolverton, W. C., and Staub, N. C.: Pulmonary transcapillary albumin flow: Effect of high pressure and increased permeability. Amer. Rev. Resp. Dis., 109: 692 (1974).

27. Vreim, C. A.. Snashall, P. D., Demling, R. H., and Staub, N. C.: Lung lymph and free interstitial fluid protein composition in sheep with edema. Amer. $J$. Physiol., 230: 1650 (1976).

28. Walker, A. M., Alcorn, D. G., Cannata, J. C., Maloney, J. E., and Ritchie, B. C.: Effect of ventilation on pulmonary blood volume of the fetal lamb. J. Appl. Physiol., 39: 969 (1975).

29. The authors thank $L$. Dong for technical assistance, $M$. Biagini for typing the manuscript, and N. C. Staub for his advice and review of the manuscript.

30. This research was supported by United States Public Health Service Pulmonary Specialized Center of Research Grants HL 14201 and HL 19185. Dr. Bressack was a trainee supported by United States Public Health Service National Pulmonary Faculty Training Center Grant HL 07159. Dr. Bland completed this work during his tenure as an Established Investigator of the American Heart Association.

31. Requests for reprints should be addressed to: Richard D. Bland, M. D., Cardiovascular Research Institute, University of California, San Francisco, CA 94143 (USA).

32. Received for publication August 14, 1978.

33. Accepted for publication October 9, 1978. 